\title{
MUUTUSED EESNIMEKASUTUSES XIX SAJANDIL MARTNA JA PALAMUSE NÄITEL
}

\author{
ANNIKA HUSSAR
}

\begin{abstract}
Annotatsioon. XIX sajandi eesnimekasutust käsitlevad vähesed varasemad ülevaated tutvustavad üldisi nimekasutusjooni või kirjeldavad kindla ajalõigu eesnimekasutust ning eesnimesid (Roos 1962; Henno 2000; Pärsik, Pae 2011). Üldteada on, et XIX sajandil eestlaste nimekasutus oluliselt muutus ning sajandi alguse tavapärased laennimed asendusid sajandi lõpuks üsna laialt uute, seni tundmatute eesnimede tarvitusega. Siinses artiklis vaadeldakse, kuidas muutused toimusid, kuidas uued nimed omaks võeti, missugused olid esimesed sammud eesnimekasutuse tänapäevastumisel.
\end{abstract}

Võtmesõnad: onomastika, antroponüümid, eesnimed, kaksiknimed

\section{Sissejuhatus}

Ülevaade Eestimaa ja Liivimaa 1900. aasta eesnimekasutusest luteri kogudustes on näidanud, et nimekasutus erines praeguse Eesti ala eri nurkades oluliselt, seda nii selle poolest, kuivõrd nimed olid muutunud võrreldes pikka aega püsinud laennimede ajastuga, kui ka piirkondlike nime-eelistuste poolest ${ }^{1}$.

XIX sajandi teisel poolel muutus eestlaste eesnimekasutus oluliselt, mitme sajandi jooksul käibel olnud laennimed hakkasid asenduma uute, võõrapäraste nimedega. Eristada saab kolme etappi, mis toovad meid tänapäeval tüüpilise nimekasutuseni 1920.-1930. aastatel. Muutuste algus on piirkonniti erinev, kuna uued nimed jm iseloomulikud jooned ilmnevad algperioodil üksikjuhuti; üldiselt võib selle paigutada XIX sajandi keskpaika. Etapid ei ole kõikjal ühesuguse järjekindlusega esindatud, eriti võib esimene etapp olla nõrgemini väljendunud.

1900. aasta andmed pärinevad Annika Hussari ettekandest „Eestlaste eesnimed 1900. aastal” XLII J. V. Veski päeval 27. juunil 2009 Tartus. 
Uute nimede kasutusele tuleku etapid saab esile tuua järgmiselt (Hussar 2009: 520-521).

Esimene etapp: käibel olnud nimede rahvusvahelised variandid. Eestipäraseks muganenud laennimed asendusid rahvusvaheliste kujudega. Mari asemel sai laps ametlikuks nimeks Marie, Kaarli asemel Karli jne. Igapäevakasutus ilmselt ei muutunud.

Teine etapp: uued võõrapärased nimed. Laennimede rahvusvaheliste kujude kasutusele tulek kergendas nende täiesti uute nimede tarvitusele võttu, millele varasemast vastet ei olnud. Sellised võiksid olla Alma, Olga, Marta, Oskar, Osvald, Voldemar. Uuemad nimed tulid kasutusse peamiselt 1870.-1880. aastatel, üksikjuhuti varem, mõnel pool hiljem. Need nimed ilmusid ametlikku kasutusse esmalt just sellisel kujul. Suulistest muganditest ehk igapäevakasutusest annavad aimu hiljem registrisse jõudnud lühivariandid (nt Tooni pro Antonie, Ruudi pro Rudolf, Volli pro Voldemar). Sellest etapist alates võib rääkida nimemoodide ja moenimede vaheldumisest Eestis. Uusi nimesid lisandus järjest rohkem, laenud tulid kaugemalt teiste rahvaste vahendusel, mida ajaliselt edasi, seda rohkem otsekontaktide kaudu.

Kolmas etapp: eestipärased nimed. Nende nimede kõrgajastuni jõuti 1930. aastatel nimede eestistamise tippajaga. Eestipäraseid nimesid soovitati esmalt eeskätt kalendrites, tuntumaks ja mõjukamaks on peetud Mats Tõnissoni kalendrit, milles uued nimed ilmusid 1880. aastatel (Annus 2000: 136-139; Rajandi, Tarand 1970: 126). Uusi nimesid leiti ilukirjandusest (Roos 1962: 415-416). Eestipärasena tutvustati ja võeti vastu ka tegelikult rahvusvahelisi nimesid, mis jutukirjanduses esinesid eestlaste nimedena, nt Linda, Hilda, Ella, Helmi (Roos 1962: 419-420). Esimesed julged eestimeelsed katsetajad valisid säärase nime lapsele juba 1870. aastatel (nt pani Carl Robert Jakobson 1874 tütrele nimeks Linda, vt Roos 1962: 416). Laiem kõlapind tekkis eestipärastel nimedel 1890.-1900. aastatel, 1920. aastatel olid need juba ülekaalu jõudnud naisenimede moes (Rajandi, Tarand 1971: 213). Uusi nimesid pandi esmalt tüdrukutele ning mõned, nagu Salme, Helmi, Linda, Õie, esinevad 1900. aastal mõnes koguduses edetabeli tipus. Neis piirkondades on üldjuhul ka esimesed etapid varem läbitud.

1900. aasta eelisnimede järgi (luteri kogudused) oli eesnimemood väga erineval tasemel. Leiab piirkondi, kus esikolmikus on veel traditsioonilised laennimed, nt Läänemaal Karusel Liisa, Jaan, Priidu, Kirblas Mari, Jaan, 
Jüri, Mihkel, Martnas Liisa, Kata, Mihklis Mari, Ann, Liisu, Jaan, Mihkel, Saaremaal Ansekülas Ann, Liisa, Hindrek, Jüri, Viljandimaal Kõpus Liisa (kõrvuti Salmega), Tarvastus Liisa, Jaan, Juhan.

On piirkondi, kus seni kasutusel olnud nimed on saanud võõrapärase kuju. Näiteks Marie Maria (pro Mari) oli 1900. aasta populaarseim naisenimi ning oli esikümnes kõigis maakondades, v.a Tartumaal ja Võrumaal. Sagedasemate nimede seas olid veel Anna $(<$ Ann), Helene $\sim$ Helena ( $<$ Leena, Leenu), Johannes ( $<$ Jaan, Juhan), Karl $\sim$ Carl $(<$ Kaarel).

Näiteid on moodsate nimede kasutuse kohta, nt Harjumaal HarjuMadisel Elwine, Rudolf, Hiiumaal Pühalepas Evald, Rudolf, Tartumaal Palamusel Alma, Elfriede, Elmar, Rudolf, Virumaal Iisakus Elfriede, Albert, Viljandimaal Helmes Ernst ja Suure-Jaanis Alma, Martha, Võrumaal Harglas Olga, Alfred, Elmar ja Vastseliinas Alfred, Osvald.

Mõnes piirkonnas on (küll ainult esialgu) naisenimede poolel populaarsust võitnud eestipäraseks arvatud nimed, nt Tartumaal Alatskivil Salme, Nõos Helmi, Salme, Palamusel Linda ja Puhjas Helmi, Viljandimaal Kolga-Jaanis Linda, Võrumaal Harglas Linda, Pärnumaal Sindis ja Vändras Helmi, Virumaal Iisakus Helmi.

Eesnimekasutus on 1900. aastal muuski mõttes erinev. Mitmiknimed levivad laiemalt XIX sajandi lõpuks, ent mitte ühtlaselt. Enam pannakse kaksiknimesid tüdrukutele. Piirkondadest tõusevad esile Virumaa ja Tartumaa, kus säärase nime saab isegi kaks kolmandikku tüdrukutest. Kahe nime mood on nõrgalt levinud Läänemaal, sh saartel, kus kaksiknimesid esineb üksikute eranditena või üldse mitte.

Nimetatud joonte järgi kujuneb välja pilt, kus paljud nimekasutuse muutustele viitavad märgid esinevad 1900. aastal Virumaal, Tartumaal ja/või Võrumaal, samas kui alalhoidlik, traditsioonilisem eesnimetarvitus on levinud Läänemaal, sh saartel.

\section{Materjal}

Arvestades eesnimekasutuses ilmnenud jooni, on valitud siinse käsitluse uurimisobjektiks kaks luteri makkogudust, Martna ja Palamuse.

Läänemaa Martna esindab varasemat nimetava. Tüdrukute esinimede seas olid 1900. a Maria Marie, Liisa, Julie, Kata ning poistel August, Johannes, Aleksander $\sim$ Alexander, Anton, Priidik. Kaks nime on saanud $14 \%$ tüdrukutest ja $9 \%$ poistest. 
Palamuse populaarsemad naisenimed olid 1900. a Alma, Adele, Elfriede, Elisabeth, Linda, Rosalie ja mehenimed August, Eduard, Elmar, Johannes, Rudolf. Kaks nime sai 36\% tüdrukutest ja 23\% poistest.

Koguduste valikul tuli arvesse veel nende võrreldav suurus. Kokku uuriti 1516 tüdruku ja 1634 poisi nime Martnas ning 1991 tüdruku ja 2118 poisi nime Palamusel. Palamuse meetrikaraamatus on saksa pihtkonna laste sünnid esitatud eraldi. Sellesse sünniloendisse on kantud põhiliselt mõisnike, ent ka teised kõrgemast seisusest perede lapsed, k.a paari eesti perekonnanimega ehk sotsiaalses hierarhias tõusnud pere lapsed. Martnas on mõisnike laste sünnikanded talupoegade omadega ühises loendis. Mõlemal juhul on kõrgemast seisusest perede lapsed analüüsist välja jäetud, nende nimed pakuvad huvi kui nimevarasse uuenduste toojad.

Ajapiirideks on võetud aastad 1834-1900. Aasta 1834 on oluline seepärast, et see tõi kaasa muutuse kirikuraamatute pidamise korras: asjakohane seadus kuulutati välja 28. detsembril 1832 ja seda hakati rakendama 1834. aastast. (Must 2000: 105-106) Seadus muutis ja ühtlustas kirikuraamatute pidamise korda ja vormi. Andmed on raamatutes üsna ühetaoliselt esitatud, ehkki piirkonniti ja aastati on erinevusi (nt vanemate-vaderite ameti märkimisel). Kuna jälgitavad muutused toimusid XIX sajandi teisel poolel, sobib 1834 ajaliseks piiriks, varasem laennimede kasutus ei ole siinse uurimuse teema. Kuna ainult viieaastase intervalliga võetud materjali käsitlus poleks lähemaks vaatluseks piisav olnud - sajandi lõpus sündide arv vähenes ning ühe aasta materjal poleks küllaldane -, käsitletakse lähemalt numbritega 4, 5, 9 ja 0 lõppevaid aastaid. Nende nelja aasta andmed on kümnendi kohta liidetud (seega kokku on seitse kümnendit). Vahepealsed aastad on üle vaadatud seisukohast, kas siis on lisandunud seni esinemata nimesid. Materjal on kogutud valdavalt Saaga kaudu Eesti Ajalooarhiivi kodulehelt, osa on saadud Siseministeeriumi rahvastiku toimingute osakonna arhiivis asunud kirikuraamatutest.

Nimede kirjutamise mõttes jääb vaadeldavasse ajavahemikku kaks olulist muutust: vana kirjaviisi vahetumine uue vastu ning 1892. aastast venestamise käigus venekeelseks muutunud kirikuraamatud.

Mõlemas koguduses on üleminekud toimunud ebaühtlaselt, kindlat ajapiiri tõmmata ei saa - erinevalt nt Kuusalust, kus Eduard Ahrens kirikuraamatus 1844. aastast järjekindlalt uut kirjaviisi kasutab (Kaugerand 2006: 14; vrd kirikuraamatuid EAA.1216.1.22; 1834-1843 ja EAA.1216.1.23; 1844-1853). Martnas minnakse uuele kirjaviisile otsustavalt üle 1872. 
aastal. Siis alustab tööd eelmise, pikaajalise pastori (1829-1872) Otto August Leopold Hörschelmanni poeg Johannes Eduard Robert (Talvoja jt 2008: 59-61). Järgmistel aastatel käekirjad vahelduvad (poeg töötas Martnas ainult kolm aastat) ning uuest kirjaviisist taganetakse: varasemad laennimed on kirja pandud pigem vanas kirjaviisis ja uued nimed järgivad valdavalt saksa kirjutustava. Uus kirjaviis saab Martnas ülekaalu 1880. aastate teisel poolel. Palamusel ilmuvad esimesed uue kirjaviisi näited Miina ja Leena 1877.-1878. a paiku, ent need näivad pigem juhuslike katsetustena ja üksikjuhtudeks jäävadki. Üldiselt kehtib sama printsiip: vanad nimed vanamoodi, uued saksa moodi. Palamusel on see seda silmatorkavam, et vanad nimed üsna pea kasutusest taanduvad, ent ka sajandi lõpupoole üksikjuhud jäävad enamjaolt vana kirjaviisi juurde.

1892. aastast käibele tulnud venekeelsed kirikuraamatud Martna ja Palamuse koguduse puhul materjalist arusaamist ei häiri. Nimi on kirillitsas, nt Мария, ja sulgudes on lisatud nimi ladina tähestikus (või vastupidi), nt Marie, Mari või Marin. (Mõnes piirkonnas on nimed ainult kirillitsas ja tegelikult mõeldud nimi jääbki teadmata.) Ka nende nimede puhul, mis ei ole ladina tähestikus, on taotlusest võimalik aru saada, nt on kirjas Mapue või Мapu, mitte lihtsustatud kuju (nt Мария).

Siiski on kirjapanekutes suuri kõikumisi. Paljudes kogudustes on eri põhjustel peetud paralleelseid raamatuid (nt mustandiraamatud). Keerulisematel juhtudel raamatuid võrreldes selgus, et nimed on kirjas isemoodi, nt ühes raamatus Rudolph, teises Rudolf, ühes Marie, teises Maria. See on ajendanud sama moodi otsustama, nagu on tehtud varasemates käsitlustes (nt Henno 2000): ühendama sama nime eri kirjakujud. Naisenimede puhul on antud ka sama nime $a$ - ja $e$-lõpulised variandid (viimaste esinemise korral on need eraldatud kaldkriipsuga, esikohal on sagedam variant).

Martna ja Palamuse kirikuraamatutes ei ole isa ametit järjekindlalt esitatud ning seda ei ole ka siin jälgitud rohkem kui huvipakkuvat tausta erandliku nime korral.

\section{3. Üldisi andmeid}

Tabelis 1 on toodud põhiandmed Martna ja Palamuse uuritavate aastate kohta, mida seejärel lähemalt kommenteeritakse.

Analüüsis keskendutakse mitmiknime esimesele nimele, teine ja kolmas nimi pakuvad huvi kui nimemoe nähtus, nimepaneku tava muutumine 
ning kui nimevalik, kus võib leiduda nimesid, mis üksiknimena ei esine. Selle aja kaksiknimed pole väljakujunenud iseseisvad kombinatsioonid, suurem osa on kombineeritud oma aja tavanimedest.

Tabel 1. Üldisi andmeid ( $\mathrm{P}$ - poisid, $\mathrm{T}$ - tüdrukud)

\begin{tabular}{|c|c|c|c|c|c|c|c|c|}
\hline Aastad & $\begin{array}{c}1834- \\
1840\end{array}$ & $\begin{array}{c}1844- \\
1850\end{array}$ & $\begin{array}{c}1854- \\
1860\end{array}$ & \begin{tabular}{|c|}
$1864-$ \\
1870
\end{tabular} & $\begin{array}{c}1874- \\
1880\end{array}$ & \begin{tabular}{|c}
$1884-$ \\
1890
\end{tabular} & $\begin{array}{c}1894- \\
1900\end{array}$ & Kokku \\
\hline \multicolumn{9}{|l|}{ Sünnid } \\
\hline Martna P & 292 & 231 & 274 & 260 & 257 & 180 & 140 & 1634 \\
\hline Martna T & 285 & 247 & 250 & 247 & 207 & 142 & 138 & 1516 \\
\hline Palamuse P & 366 & 284 & 331 & 327 & 316 & 262 & 232 & 2118 \\
\hline Palamuse T & 315 & 301 & 339 & 311 & 286 & 237 & 202 & 1991 \\
\hline \multicolumn{9}{|l|}{ Nimede arv } \\
\hline Martna P & 33 & 31 & 28 & 27 & 30 & 30 & 28 & 70 \\
\hline Martna T & 25 & 18 & 21 & 25 & 26 & 28 & 26 & 63 \\
\hline Palamuse P & 44 & 38 & 39 & 40 & 51 & 45 & 48 & 103 \\
\hline Palamuse T & 28 & 42 & 39 & 37 & 44 & 48 & 57 & 116 \\
\hline \multicolumn{9}{|c|}{ Ühe nime kohta kandjaid } \\
\hline Martna P & 8,9 & 7,5 & 9,8 & 9,6 & 8,6 & 6 & 5 & 23,3 \\
\hline Martna T & 11,4 & 13,7 & 11,9 & 9,9 & 8 & 5,1 & 5,3 & 24,1 \\
\hline Palamuse P & 8,3 & 7,5 & 8,5 & 8,2 & 6,2 & 5,8 & 4,8 & 20,6 \\
\hline Palamuse T & 11,3 & 7,2 & 8,7 & 8,4 & 6,5 & 4,9 & 3,5 & 17,2 \\
\hline \multicolumn{9}{|c|}{ Kahe ja enama nime osakaal \% } \\
\hline Martna P & 1,7 & 3,0 & 3,3 & 1,2 & 5,5 & 7,2 & 5,7 & \\
\hline Martna T & 2,8 & 1,6 & 5,2 & 4,1 & 5,8 & 7,8 & 11,6 & \\
\hline Palamuse P & 1,6 & 2,3 & 2,4 & 6,4 & 17,8 & 23,6 & 23,8 & \\
\hline Palamuse $\mathrm{T}$ & 1,4 & 7,4 & 7,6 & 15,9 & 42,1 & 48,5 & 39,7 & \\
\hline \multicolumn{9}{|c|}{ Esinime osakaal \% } \\
\hline Martna P & 19,2 & 12,6 & 14,2 & 15 & 12,8 & 18,3 & 18,6 & \\
\hline Martna T & 17,9 & 22,3 & 17,2 & 14,2 & 15,5 & 16,2 & 18,8 & \\
\hline Palamuse P & 12,6 & 15,9 & 14,8 & 11,6 & 16,1 & 19,9 & 14,2 & \\
\hline Palamuse T & 18,1 & 15 & 10,9 & 11,3 & 14,3 & 11,8 & 9,9 & \\
\hline \multicolumn{9}{|c|}{ Kümne eelisnime osakaal \% } \\
\hline Martna P & 80,8 & 80,1 & 79,2 & 82,3 & 82,1 & 79,5 & 83,6 & \\
\hline Martna T & 88,4 & 91,9 & 88,4 & 87,8 & 83,1 & 82,4 & 82,9 & \\
\hline Palamuse P & 73,5 & 72,2 & 81,3 & 75,5 & 64,8 & 68,7 & 68,1 & \\
\hline Palamuse T & 82,9 & 76,4 & 75 & 71,4 & 65,7 & 59,5 & 51,5 & \\
\hline
\end{tabular}


Joonis 1 näitab nimekandjate arvu ühe nime kohta. Selleks on laste arv jagatud vastava perioodi nimede arvuga. Tegelikkuses nimed loomulikult ühtlaselt ei jaotu, osa nimesid kasutatakse väga sagedasti, teisi leidub vaid korra. XIX sajandi Martna ja Palamuse nimekandjate arvu suhe ühe nimega on aga kaunis kõnekas. Esiteks maksab tähele panna, et 1830. aastad osutavad varasemale nimekasutusele, kui tarvitusel oli rohkem mehe- kui naisenimesid, nagu on väidetud XVIII sajandi nimekasutuse kohta nii meil kui ka mujal (Rootsmäe 1969: 623; Kiviniemi 1982: 175-176). XIX sajandi lõpus, kui pruuki tuli suur hulk uusi nimesid, hakati neid kergemini andma tüdrukutele kui poistele. Nii Martnas kui ka Palamusel on sajandi esimesel poolel käigus vähem naisenimesid ning nende kasutussagedus on suurem. See vahe on 1860. aastateks tasandunud. Sajandi viimasel kümnendil on erinevused seotud juba pigem piirkonnaga kui sooga. Kuigi mõlemas koguduses on selgelt rohkem nimesid kasutusel, on kõige enam kasvanud uute naisenimede hulk Palamusel.

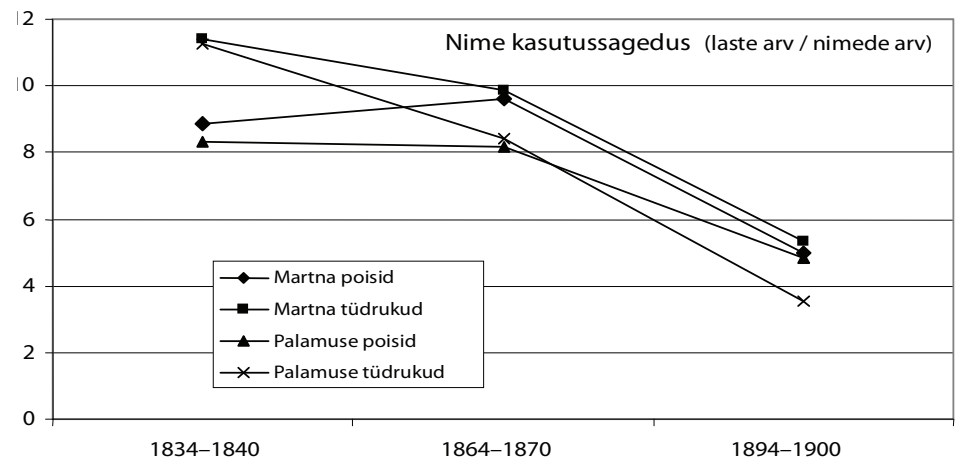

Joonis 1. Ühe nime kasutussagedus Martnas ja Palamusel

Samalaadseid tendentse kinnitavad muutused vanemate ning ristivanemate nimede andmisel vastsündinutele XIX sajandil (Hussar 2009). Martna kõrval asuvas Ridala koguduses on 1840. aastal 45\% tüdrukutest saanud vaderi ja $20 \%$ ema nime, 1890 . a aga vastavalt ainult $20 \%$ ja $3 \%$. Ridala poistest on 1840 . a ligi $40 \%$ saanud vaderi nime ja $17 \%$ isa nime. 1890 . a on vaderite-vanemate nimede osatähtsus poiste puhul kahanenud (vastavalt $32 \%$ ja $7 \%$-ni), ent mitte nii oluliselt kui tüdrukutel. Palamusel on 1840. a saanud vaderi nime $70 \%$ lastest. Ema-isa nimi on Palamusel vähem edasi kandunud, 1840. a sai 1\% tüdrukutest ema nime (1890 ei ükski), isa 
nime osakaal poja nimena on vähenenud 5\%-lt 1,4\%-ni. Vaderite nimede suurema osatähtsuse puhul tuleb tähele panna, et arvesse on võetud ka seda tüüpi juhud, kui nt Marie on nime saanud ristiema Mari järgi. Seega on Palamusel olnud suurem tähtsus ristivanemate, Ridalas aga vanemate nimedel. Mõlemad tendentsid on sajandi teisel poolel taandunud, eriti ema nime edasikandumine.

\section{Eelisnimed}

\subsection{Eelisnimede osakaal nimepanekul}

Nimekasutust iseloomustab eelisnimede osa nimeandmisel. 1830. aastate nimekasutus osutab selgelt varasemale olukorrale, kus väike hulk nimesid kattis suure osa mingi perioodi nimevajadusest. Edgar Rajandi on esile toonud, et XVIII sajandi esimesel poolel on Ambla kihelkonnas 10 populaarsemat nime katnud 72\% nimevajadusest (Rajandi 1963: 177). Lemming Rootsmäe on leidnud, et Võnnu kihelkonnas on XVIII sajandil eelisnimede tähtsus isegi kasvanud: sajandi alguse 66\%-lt 74\%-ni poistel ja 60\%-lt 82\%-ni tüdrukutel (Rootsmäe 1969: 623). Seega näib XVIII sajandi nimevalik olnuvat isegi rikkalikum. Kairit Henno (2000) andmed XIX sajandi esimese poole mehenimede kohta Pöides näitavad umbes sama: 10 eelisnimega on ristitud $73,3 \%$ poisslastest. 1840 . aasta kohta tehtud uurimus väidab, et ligi kolmveerand tüdrukutest ning kaks kolmandikku poistest on saanud nime 10 populaarsema hulgast (Pärsik, Pae 2011: 518, 522). Sama laadi tulemustele viitab Henn Saari uurimus (1990).

Martna ja Palamuse andmed esinime ja esikümne kohta on toodud tabelis 1 .

Kuivõrd kõige rohkem on sel perioodil muutunud Palamuse tüdrukute nimepanek ning kõige vähem Martna tüdrukute oma, võrreldakse siinkohal nende eelisnimede kasutust (vt joonis 2).

Martna tüdrukute eelisnimede osakaal väheneb sel ajal üsna vähe. 1840-ndate nimekasutus näitab, kui suurt osa võib mängida ühe nime populaarsus: esinime Marri kasutussagedus (22\%) kergitab kogu esikümne tähtsust.

Palamuse tüdrukute eelisnimede osakaal on kooskõlas eespool näidatud ühe nime keskmise kasutussagedusega ning järgnevalt esitatud muutustega nimevalikus. Kui 1830-ndatel saab nime esikümne hulgast u 83\% tüdrukutest, siis sajandi lõpus pisut üle poole. Eelisnimede osatähtsus 
väheneb oluliselt, mis tähendab suuremat muutust nimevalikus, samuti uute nimede väiksemat kasutust. Väheneb ka esinime osakaal, 1830-ndate ligi viiendikult sajandi lõpu vaevalt kümnendikuni.

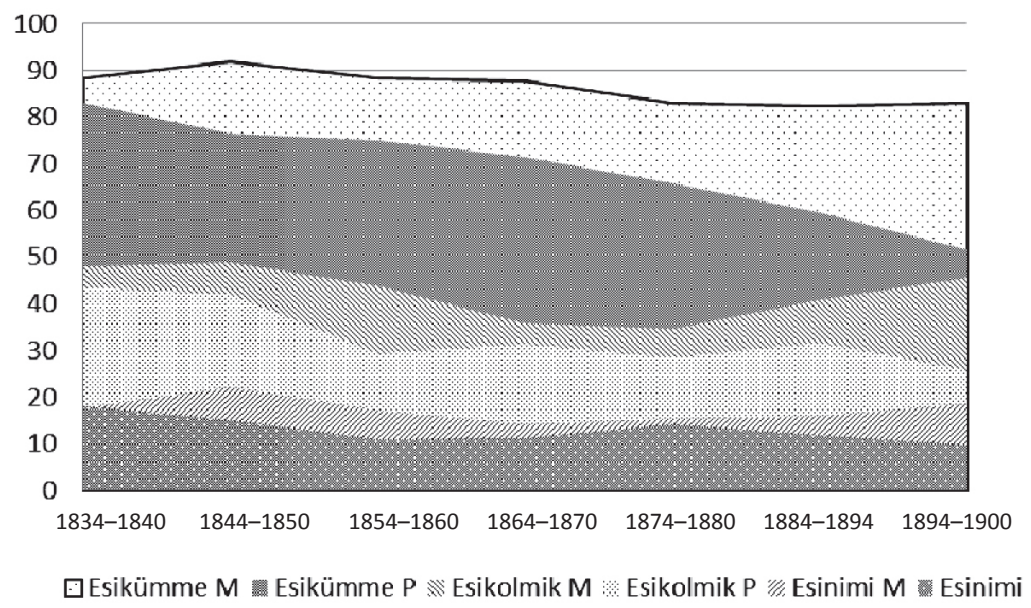

Joonis 2. Martna (M) ja Palamuse (P) tüdrukute eelisnimede osakaal \%

\subsection{Eelisnimed soo kaupa}

Populaarsemaid nimesid on otstarbekam vaadata eeskätt soo kaupa missugused on Martna ja Palamuse eelistused. Piirkondlikult pakub huvi, missugune on traditsiooniliste nimede osakaal, millal need nimed pruugist taanduvad, millega asendatakse, ning lõpuks, millal ilmuvad märgid XX sajandi esimese poole suundumusest, eestipärastest nimedest.

Tabelites 2 ja 3 on esitatud vastavalt 10 populaarsemat mehe- ja naisenime koos nende kasutussagedusega. Nimed on antud meetrikas esinenud kujul, mitme variandi puhul on valitud kõige sagedam kuju.

\subsubsection{Poiste eelisnimed}

Vaadeldud ajavahemiku kolme esimese kümnendi (1834-1860) mehenimed esindavad varasemat, laennimede aega. Martna ja Palamuse nimed osalt erinevad, osalt kattuvad, seda nii varasema kui ka hilisema nimekasutuse puhul. 
Ühistest nimedest kuuluvad varasemasse aega Ado, Hans $\sim$ Hants, Hinrik Hindrik, Jaan, Juh(h)an, Jür(r)i, Ka(a)rel, Kristian Kristjaan, Kustas, Kustaw, Maddis, Mart, Mihkel, Peter, Prits, Sassa $\sim$ Sascha, Tawet, Tönnis, Willem. Osa neist esineb vaid mõni kord. Hilisematest nimedest on ühised Adolph, Aleksander $\sim$ Alexander, Alfred, Arthur, August, Bernhard, Karl Carl, Eduard, Ernst, Ferdinand, Friedrich, Gustav, Heinrich, Herman(n), Johannes, Julius, Konrad Konrat, Kristohwer Kristofer, Ludwig, Martin, Oscar $\sim$ Oskar, Otto, Paul, Richard, Wilhelm, Woldemar.

Varasemast nimekasutusest leiduvad ainult Martnas nimed Andrus, Kristow, Moritz, Pri(i)dik, Pri(i)do Priidu, Prommold, Rein, Reinut, Sassi, ning Palamusel nimed Andres, Dannel, Elias, Gusti, Hendrik, Hindri, Jaak, Kotlip, Laar, Ludwi, Maddi, Markus, Mats, Mik, Märt, Pärtel, Tannel, Tanni, Tomas, Tönno, Widrik. Mõned harva esinevad nimed kajastavad pigem endist nimepruuki, osa võivad olla mujalt tulnute nimed. Sagedamini kasutatutest võiks Martnast esile tuua nimed Priidu ja Priidik. Mõne korra esineb Prommold, mille vahendajaks ja/või nime-eeskujuks võib olla Eylandtite köstripere, kes mitme põlve vältel Martnas tegutses ning kelle igas põlvkonnas oli nimi esindatud: Fromhold (snd 1773) oli Christian Johann Eylandti (köster 1754-1796) kaheksas laps; Fromholdi noorema venna David Gabriel Eylandti (köster 1796-1835) seitsmes laps August Fromold oli omakorda järgmine köster (1837-1873) (Talvoja jt 2008: 74-77). Palamusel esinevad korduvalt nimed Elias ja Ludwi, mis ei ole väga tavalised. Esimene kaob vaadeldud perioodi lõpuks tarvitusest, teise asemele tuleb Ludwig. Nime vahendajaks võib olla Palamuse pastor (1818-1844) Ludwig Karl Friedrich Kolbe.

Hilisematel kümnenditel on ainult Palamusel esinenud nimede loetelu pikem: Abel, Adam, Adalbert, Adelbert, Albert, Albrecht, Alfons, Arnold, Arwed, Benjamin, Burchard, Elmar, Eugen, Georg, Gottlieb, Harry, Helmar, Helmer, Herbert, Hugo, Isak, Magnus, Michael, Nikolai Nicolai, Oswald, Ottomar, Paulus, Robert, Rudolf $\sim$ Rudolph, Samuel, Simon, Theodor. Osa neist nimedest on Martna üldist alahoidlikkust arvestades liiga uued, mõned nimed on aga kogu Eestit silmas pidades harukordsed. Siiski tuleb ka Martnas esile huvitavaid näiteid: Anton, Arwid, Constantin, Erich, Feliks, Fromhold, Georg, Hendres, Reinold, Roman ja Werner. Neist on näiteks Anton Martna edetabeli nimesid ning mujalgi Eestis üsna tavaline, ent Palamusel ei esine. Fromhold asendab varasemat Prommoldit, 


\begin{tabular}{|c|c|c|c|c|c|c|c|c|c|c|c|c|c|c|c|c|c|c|c|c|c|c|c|}
\hline & & $\begin{array}{l}0 \\
\infty \\
=\end{array}$ & $\begin{array}{l}0 \\
2\end{array}$ & $\vec{\simeq}$ & $\hat{0}^{\circ}$ & $\sigma^{2}$ & $\begin{array}{l}\nabla_{0} \\
\end{array}$ & in & $\hat{\gamma}$ & & $\vec{\sim}$ & & & $\begin{array}{l}\mathcal{N} \\
\pm \\
\pm\end{array}$ & $\begin{array}{l}a \\
\tilde{c}\end{array}$ & $\vec{a}$ & $\mid \begin{array}{l}n \\
0\end{array}$ & $\begin{array}{l}0 \\
\text { in }\end{array}$ & & $\stackrel{m}{8}$ & & & $\tilde{r}$ \\
\hline ஓ & & $\begin{array}{l}\overrightarrow{0} \\
\stackrel{0}{0} \\
\vec{Z} \\
\vec{z}\end{array}$ & 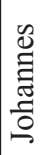 & $\begin{array}{l}\tilde{0} \\
\stackrel{0}{0} \\
\text { 完 }\end{array}$ & 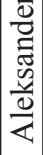 & 次 & $\begin{array}{l}\bar{D} \\
\stackrel{\Xi}{\vec{U}} \\
\end{array}$ & 点 & 苞 & 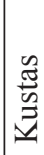 & $\Xi$ & 疋 & & 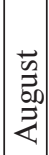 & 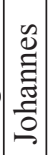 & 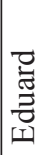 & 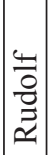 & 올 & 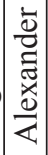 & 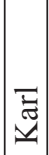 & $\frac{\vec{\Xi}}{\stackrel{\Xi}{\Xi}}$ & $\begin{array}{l}\frac{\pi}{Z} \\
\underline{U} \\
\underline{U}\end{array}$ & 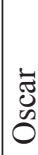 \\
\hline & & $\begin{array}{c}m \\
\infty \\
-1\end{array}$ & & 官 & 으 & $N$ & $\overrightarrow{6}$ & $\begin{array}{l}0 \\
10\end{array}$ & $\stackrel{\nabla}{\forall}$ & $\hat{\sigma}$ & $\infty$ & & & $\hat{\Omega}$ & $\sigma^{2}$ & กू & $\hat{n}^{\circ}$ & in & $n$ & $\begin{array}{l}\mathcal{N} \\
f\end{array}$ & $\stackrel{\mathrm{N}}{\underset{f}{*}}$ & $\vec{m}$ & $\widehat{\vec{N}}$ \\
\hline $\begin{array}{l}\infty \\
\infty \\
\infty\end{array}$ & & $\begin{array}{l}\stackrel{0}{0} \\
\stackrel{\Xi}{Z}\end{array}$ & 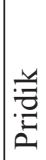 & 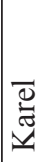 & 胥 & 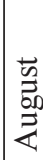 & 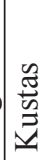 & 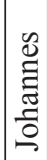 & $\frac{0}{0}$ & 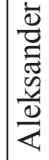 & 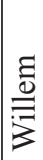 & & & 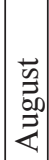 & 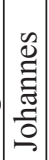 & 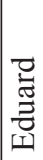 & 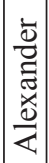 & $\frac{\pi}{\tilde{J}}$ & 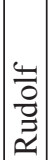 & $\mid \begin{array}{c}\text { 壳 } \\
\text { I }\end{array}$ & 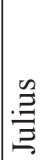 & $\begin{array}{l}\text { 려 } \\
\text { D } \\
0\end{array}$ & ص \\
\hline$\varnothing$ & & $\begin{array}{l}\infty \\
\mathfrak{d}\end{array}$ & $\vec{\simeq}$ & $\approx$ & $\tilde{n}^{n}$ & $a^{2}$ & & $\begin{array}{l}0 \\
0\end{array}$ & $\begin{array}{l}n \\
n\end{array}$ & & & & & 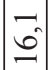 & నn & $0^{0}$ & $\hat{n}$ & $\begin{array}{l}\nabla_{0} \\
\text { in }\end{array}$ & & & $\begin{array}{l}\infty \\
m\end{array}$ & & $\tilde{n}$ \\
\hline$\underset{\infty}{\frac{1}{\infty}}$ & & $\underset{\Xi}{\Xi}$ & $\begin{array}{l}\bar{D} \\
\stackrel{\vec{Z}}{ }\end{array}$ & $\frac{y}{\bar{y}}$ & 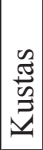 & $\mid \begin{array}{l}0 \\
0 \\
\text { 曾 }\end{array}$ & 章 & $\Xi$ & $\underset{\tilde{\Xi}}{\tilde{\Xi}}$ & 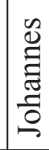 & $\frac{0}{0}$ & & & 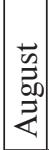 & 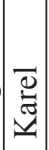 & 疍 & 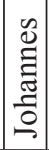 & 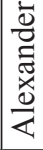 & $\bar{\Xi}$ & 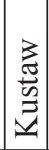 & 总 & 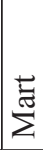 & 胥 \\
\hline$\stackrel{2}{R}$ & & & 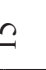 & $\begin{array}{l}\sigma_{0} \\
0 \\
0\end{array}$ & $\begin{array}{l}0 \\
0\end{array}$ & $\Omega^{\circ}$ & $\hat{\sigma}$ & in & & $\begin{array}{l}0 . \\
f\end{array}$ & & $\tilde{m}$ & & $\begin{array}{l}0 \\
= \\
=\end{array}$ & $\underline{=}$ & $\infty$ & 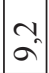 & $\stackrel{n}{n}$ & $\overrightarrow{6}$ & $\begin{array}{l}\infty \\
\text { in }\end{array}$ & $n$ & $\begin{array}{l}0 \\
f\end{array}$ & $\stackrel{m}{\sigma}$ \\
\hline ఫे & & $\begin{array}{c}\mathbb{E} \\
\stackrel{\Xi}{\Xi}\end{array}$ & $\begin{array}{l}\bar{D} \\
\bar{\Xi} \\
\underline{U}\end{array}$ & $\Xi$ & 总 & 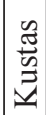 & 遈 & 记 & 点 & 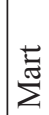 & $\stackrel{\frac{1}{0}}{\stackrel{0}{2}}$ & 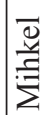 & & 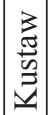 & 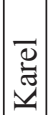 & 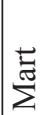 & 蔦 & 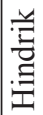 & 窇 & $\Xi$ & 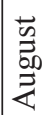 & 胥 & $\begin{array}{l}\overline{0} \\
\frac{y}{\Xi} \\
\Sigma\end{array}$ \\
\hline 8 & & $\begin{array}{l}\sim \\
\pm\end{array}$ & $\simeq$ & $\approx$ & $\begin{array}{l}0 \\
0 \\
0\end{array}$ & $\vec{a}$ & గู & $\begin{array}{l}\infty \\
i\end{array}$ & $\bar{m}$ & $m$ & ते & & & $\begin{array}{l}\infty \\
\underbrace{\prime}\end{array}$ & 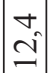 & $\widetilde{\sim}$ & 의 & a & & & $\vec{n}$ & $\stackrel{n}{\nabla}$ & $\stackrel{+}{\sim}$ \\
\hline 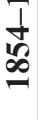 & & 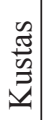 & $\begin{array}{l}\bar{D} \\
\bar{\Xi} \\
\underline{\Xi}\end{array}$ & 胥 & $\Xi$ & 足 & $\sum_{\Sigma}^{ \pm}$ & 递 & 总 & 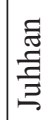 & 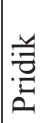 & & & $\mid \begin{array}{l}\bar{D} \\
\vec{\Xi} \\
\underline{v}\end{array}$ & $\sum_{\bar{z}}^{\bar{z}}$ & 疍 & 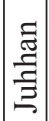 & $\Xi$ & 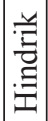 & 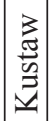 & $\begin{array}{l}\overline{0} \\
\frac{y}{z} \\
\sum\end{array}$ & 胥 & 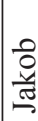 \\
\hline 8 & & & & $\stackrel{N}{ }$ & $=$ & 의 & n & & $\begin{array}{l}\infty \\
f^{\prime}\end{array}$ & $m$ & $\begin{array}{l}0 \\
\text { in }\end{array}$ & & & 0 & $\hat{\sigma}$ & & & 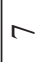 & & & 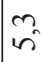 & ले & $\infty$ \\
\hline$\underset{\infty}{+}$ & & 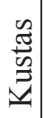 & $\begin{array}{l}\bar{D} \\
\underline{\Xi} \\
v\end{array}$ & 记 & $\Xi$ & 胥 & 竞 & $\frac{0}{0}$ & 胥 & 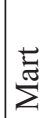 & 疍 & & & $\mid \begin{array}{l}\vec{D} \\
\stackrel{\vec{t}}{\Xi} \\
\mid\end{array}$ & 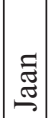 & $\Xi$ & $\stackrel{\bar{z}}{\Sigma}$ & $\begin{array}{l}\text { ज्ञ } \\
\frac{\mathcal{I}}{\Xi} \\
\end{array}$ & 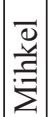 & 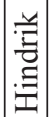 & 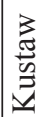 & 胥 & $\sum^{:}$ \\
\hline$\stackrel{9}{+}$ & & $a^{n}$ & $\approx$ & $\stackrel{n}{\simeq}$ & $\begin{array}{l}0 \\
\infty\end{array}$ & No & ชู & $n$ & $\stackrel{\nabla}{\sigma_{0}}$ & $\vec{m}$ & $\infty$ & & & $\begin{array}{l}0 \\
0 \\
0\end{array}$ & $\simeq$ & $\mathfrak{n}^{n}$ & $a$ & $\underset{\infty}{N}$ & $\sqrt{-}$ & $\sigma^{\circ}$ & $\stackrel{\nabla}{\nabla}$ & $m$ & $\widehat{\widetilde{N}}$ \\
\hline$\frac{1}{\infty}$ & & 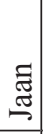 & $\Xi$ & $\begin{array}{l}\overline{0} \\
\vec{J} \\
\underline{U}\end{array}$ & 吕 & 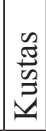 & 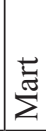 & $\begin{array}{l}\overline{0} \\
\frac{y}{J} \\
\dot{z}\end{array}$ & 点 & 胥 & 远 & & 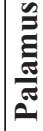 & $\Xi$ & $\sum_{\bar{Z}}^{ \pm}$ & 胥 & 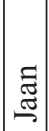 & $\begin{array}{l}\bar{D} \\
\text { Jै } \\
\underline{v}\end{array}$ & 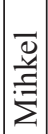 & 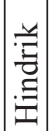 & :0 & $\begin{array}{l}\frac{0}{0} \\
\frac{\sqrt{c}}{\mathrm{I}}\end{array}$ & 点 \\
\hline$\frac{4}{\Xi}$ & & - & ن & $\dot{r}$ & $\dot{\theta}$ & is & $0^{\circ}$ & 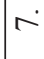 & $\infty$ & $a^{\circ}$ & $\stackrel{0}{0}$ & & & $-i$ & i & $\dot{r}$ & $\dot{\nabla}$ & in & 6 & $\sigma^{\circ}$ & $\infty$ & $a^{\circ}$ & 으 \\
\hline
\end{tabular}


Reinold varem esinenud Reinu ja Reinutit. 1880. a sündinud Hendres oli Mari ja Peet Tomassoni poeg, kelle ristivanemad olid samuti eestlased. Eestistamisel on ta vahetanud nime Heinu vastu.

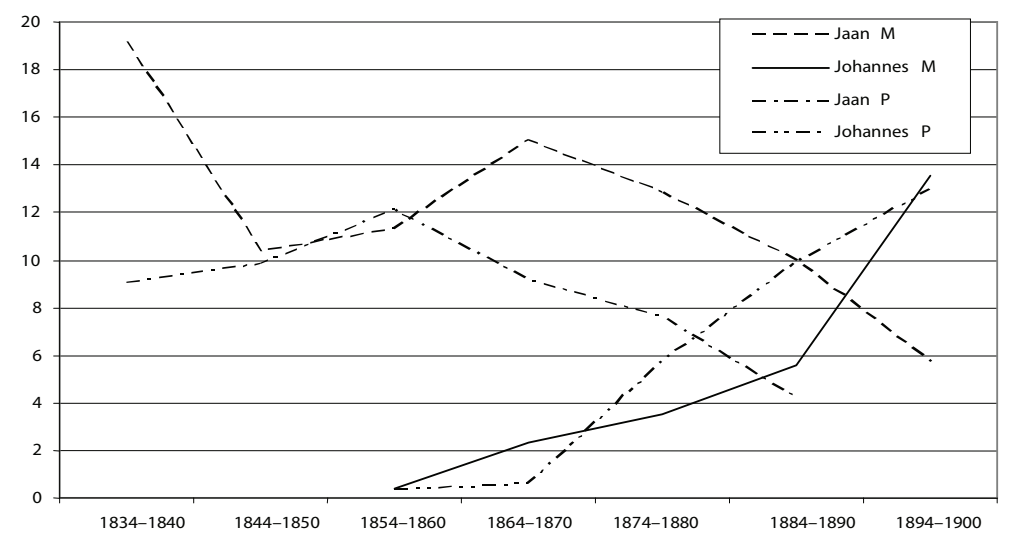

Joonis 3. Jaani ja Johannese kasutus Martnas (M) ja Palamusel (P)

Joonisel 3 on kujutatud XIX sajandi ühe levinuma nime, Jaani vahetumine Johannese vastu. Johannes asendas Jaani ja Juhanit üsna laialt, ent igal pool Johannes eelkäijate edu ei saavutanud. Jooniselt on näha, et Palamusel Jaani sajandi lõpus enam ei esine, Johannes on ülekaalu saanud 1870. aastatel. Martnas on kohavahetus toimunud kümnendi võrra hiljem, kuid ka Jaan on jäänud edasi tarvitusse.

Mõlemas piirkonnas on Johannes sajandi lõpus väga populaarne, erinevus seisneb edetabelis nende kõrval seisvates nimedes. Martnas on sajandi lõpus tervelt neli nime - Karel, Jaan, Kustas, Jüri-, mis on populaarsemate seas olnud kogu vaadeldud aja. Anton ja Pridik on esikümnes sajandi keskpaigast, 1880-ndatest August ja Aleksander, päris uued nimed on Gustav ja Eduard. Palamuse esikümme koosneb kas 1880-ndatel kasutusse ning siis ka esikümnesse jõudnud nimedest, nagu Rudolf, Karla, Oscar, päris uutest nimedest, nagu Hugo ja Elmar, või kõige varem 1850. aastatel laiemalt levinud nimedest, nagu August, Eduard, Alexander, Karl.

Seega võib Palamuse selge muutuse paigutada 1870. aastatesse, kui esikümnes on vahetunud viis nime, mida 1830-ndatega võrreldes varem ei esinenud. Martnas on eelisnimed samasuguse muutuse läbi teinud 1880.-1890. aastatel. 


\subsubsection{Tüdrukute eelisnimed}

Tüdrukute eelisnimed on ilmekamad. Esikümme on esitatud tabelis 3.

Martna ja Palamuse ühised nimed varasemast nimekasutusest on An(n), Anna, Anno, Elise, Elts Els, Ju(u)la, Ju(u)li, Kadri, Kai, Kat(t)a, Krö(ö)t $\sim$ Kreet, Le(e)na, Le(e)no Leenu, Li(i)sa, Li(i)su Li(i)so, Mai, Marri, Mi(i)na, Tio, Truta, Truto, Wio. Hilisematest nimedest esinevad mõlemas koguduses Alide, Al(i)ne, Alma, Annette, Elisabeth, Elwine, Emilie, Helene/a, Hermine, Hilda, Ida, Johanna, Julie, Kat(t)ari(i)na Kattarina/e, Leontine, Louise, Lowi(i)sa, Maria/e, Martha, Olga, Pauline, Rosalie, Sophiela, Teresa $\sim$ Therese, Wilhelminela.

Ainult Martnas esinevad varasemas kasutuses Edo, Katti, Madlena, Tina; Palamusel Anlena, Anni, Ello, Ewa, Leen, Leeni, Lina, Madli, Mal, Mali, Marre, Mili, Sohwi, Trino. Tina ja Edo on Martnas tavalised nimed, sama võib öelda Palamuse Ewa, Mali, Mili, Sohwi ja Trino kohta. Muud jäävad harvaks või üksikjuhuks. Huvitav juhtum on Anlena, mis on kahel korral esinenud kujul An Lena (1850.-1860. aastatel), ent mida on ilmselt sedavõrd kokkusulanuna tajutud, et on ka kokku kirjutatud (nt 1854 esineb vaderina Anlena Steinmann).

Kuna Martna nimede uuenemine on hilisem, pole sealne Palamusest erinevate uute nimede loetelu kuigi pikk: Clara, Friederike, Irene, Karolina, Margot, Nora, Regine. Täpsustada tuleb, et Nora esineb korduvalt juba 1782. a hingerevisjonis. Taas leidub köster Christian Johann Eylandti peres vähemalt kaks võimalikku nime vahendajat: tema teise tütre (snd 1760) nimi oli Eleonora Catharina ning kolmas abikaasa (snd 1751) oli Nora (Talvoja jt 2008: 75).

Martnast erinevate Palamuse naisenimede loendis on Adele, Adelheid, Adolfine, Agathe, Agnes, Alfine, Alwine, Amaliela, Amanda, Antonie, Armanda, Armilde, Auguste, Aurora, Bertha, Betty, Carolina $\sim$ Karolina/e, Charlotta, Christine, Clorinde, Dorothea, Elfriede, Elisa, Elly, Elsa, Emma, Euphrosina, Hedwig, Heinriette, Hulda, Irlanda, Juliana, Käte, Laurine, Marichen, Mathilde, Meta, Mimi, Natalie, Pauline, Selma, Senta, Wally, Virginie. Neist mõned esinevad Palamuse esikümnes, mõned on mujal Eestis laiemas kasutuses, ent leidub haruldusi, mis ka Palamusel esinevad korra ning sel juhul teise või kolmanda nimena. 
Huvitavad on nimed, mis on võinud esineda igapäevapruugis ning mis on alles nime mõningase tarvituse järel ametlikku registrisse jõudnud. Martnas on sellised Minni ( $<$ Minna, Wilhelmine), Taali $(<$ Natalie), Tooni ( $<$ Antonie), Wisa ( $<$ Lowisa), Palamusel Adi $(<$ Adele), Rosa, Rosi $(<$ Rosalie), Sina $(<$ Euphrosina).

XIX sajandil eestipärasena esitatud või käsitatud nimesid esineb arvukamalt Palamusel, need on Ella, Elma, Elmi, Hella, Helmi, Lilla, Lilli, Linda, Salme. Martnas esineb ainult üks nimi - Salme: 1894 on ristitud Margot Eleonore Salme, kaupmees Peter Hanseni tütar.

Olgu nimetatud, et eestipäraseid mehenimesid leidub kahe piirkonna peale üks: Palamusel on Juhan Sein 1887 ristinud poja nimega Ülo.

Edetabelite järgi võib märgata, et Palamusel on muutused varasemad ning ulatuslikumad. 1830. aastatel on mõlemas piirkonnas kasutusel veel varasemate nimede valik, eelisnimede seas näeme tavapäraseid laennimesid, osa neist on ühised, osa kohalikule traditsioonile iseloomulikud. Martna Anna ja Palamuse Lisa võivad viidata kõrgemasse seisusesse kuulunute eelistustele, millest hiljem suuremad muutused välja kasvavad. Palamuse 1830. aastate esiviisikust on kõik nimed kasutusest taandunud 1880. aastateks, Martnas on selleks ajaks kõrvale jäänud Mai ja An, ent muud leiavad mõningal määral kasutamist sajandi lõpuni. Olulisemalt on Palamuse nimekasutus muutunud 1870. aastateks, kui esimeste kümnenditega võrreldes on kasutusest kadunud kuus nime, asemele on tulnud Mariale, Pauline, Amalie, Emilie, Julie, Rosalie, Lowisa. 1890. aastatel on Palamuse eelisnimede seas täiesti uued nimed, ainult Helene/a langeb kokku eelmise kümnendiga. Seega saab Palamuse tüdrukute puhul nentida varasema nimetava muutumist.

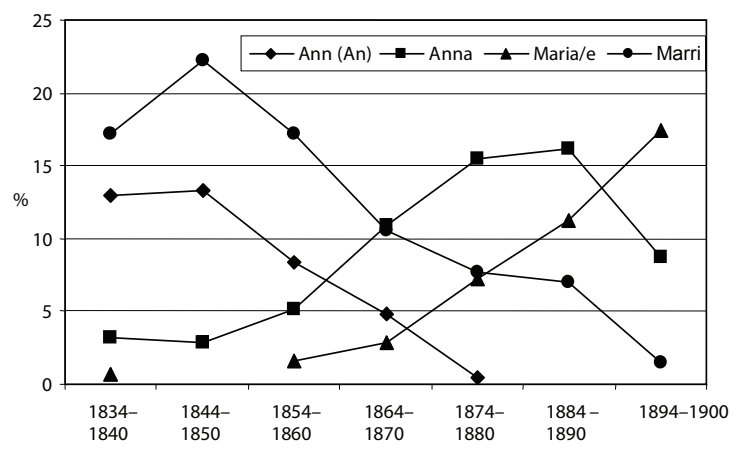

Joonis 4. Marie ja Anna Martnas 


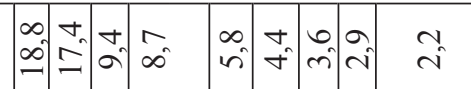

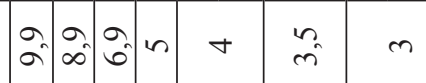

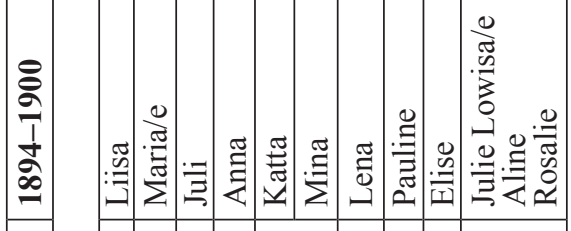

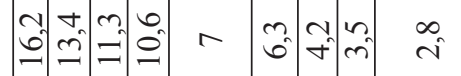

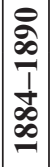

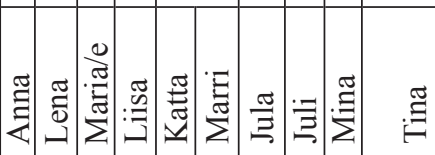

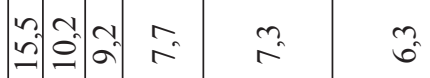

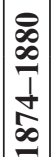

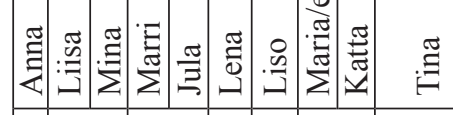

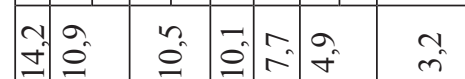

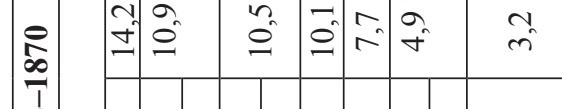

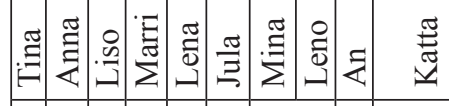

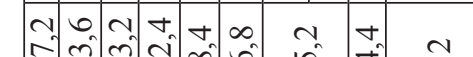

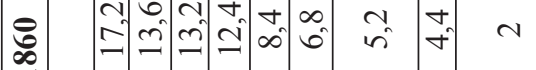

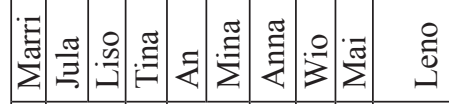

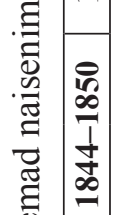

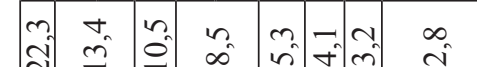

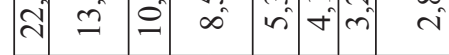

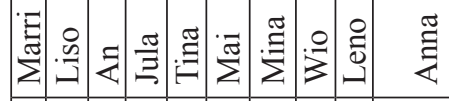

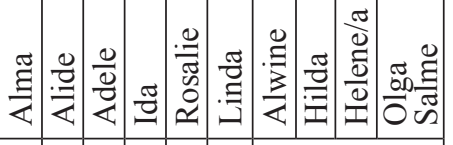

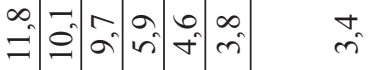

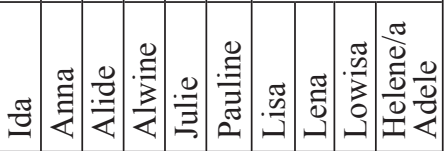

$y^{2} \infty$
in

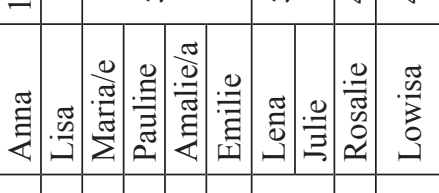

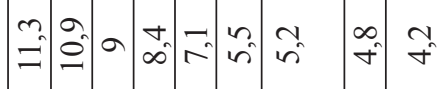

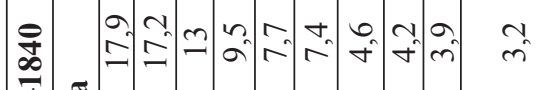

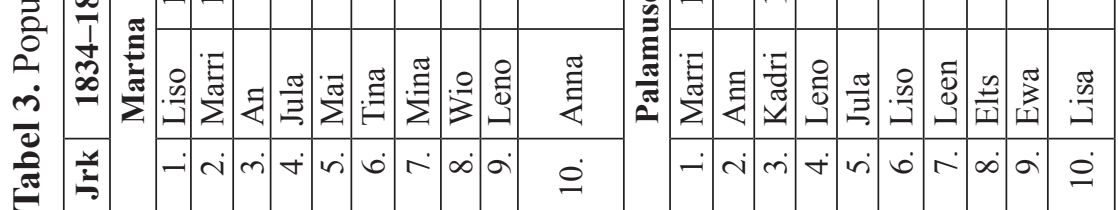


Huvitava võrdluse pakub nime Ann vahetumine Anna vastu ning Marri vahetumine Marie/a vastu (vt joonised 4 ja 5). Võõrapärasem kuju saavutab ülekaalu mõlemas piirkonnas ligikaudu samal ajal, 1860-ndatel. Martnas jätkub uute variantide edu sajandi lõpuni, ka Mari on veel tarvituses, ent Palamusel kaovad Ann ja Mari pruugist järgmise kümnendiga, huvi vaibub sajandi lõpuks Anna ja Marie/a vastu üpris tagasihoidlikuks. (Palamusel on Marie/a olulisel kohal kaksiknimede teise nimena, ent ka selles rollis on kõrgaeg 1870. aastatel - nagu üksiknimenagi.)

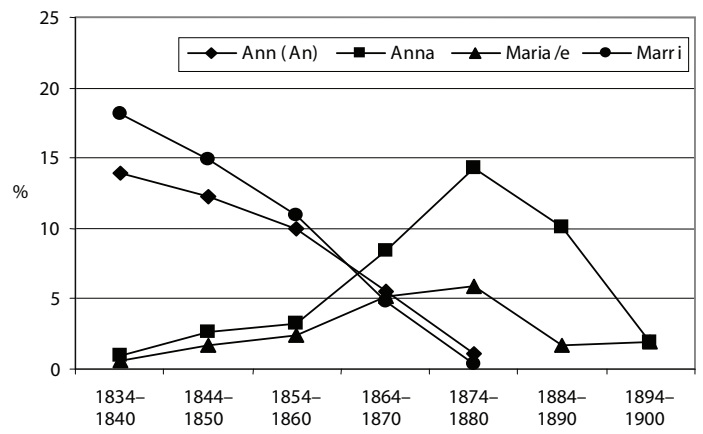

Joonis 5. Marie ja Anna Palamusel

Palamuse nimede uuenduslikkus tuleb hästi esile, kui võrrelda sajandi viimase kümnendi esiviisiku naisenimede mooditulekut (vt joonised 6 ja 7).

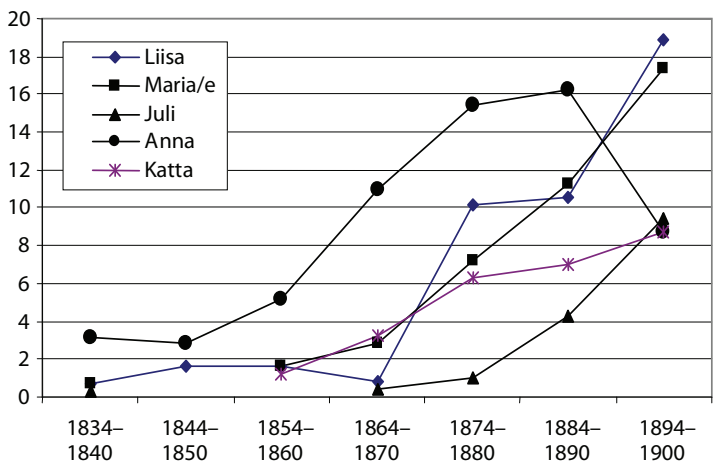

Joonis 6. 1890. aastate esiviisiku nimede kasutusse tulek. Martna tüdrukud (T) 


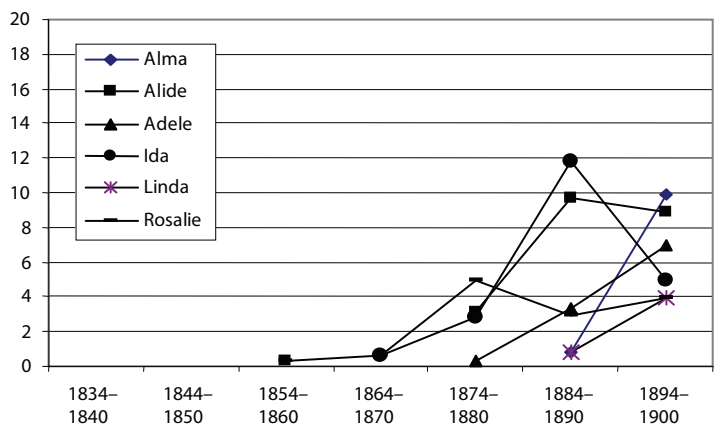

Joonis 7. 1890. aastate esiviisiku nimede kasutusse tulek.

Palamuse tüdrukud (T)

Torkab silma, et Palamuse 1890-ndate eelisnime Alma kasutus ulatub vaevalt $10 \%$-ni. See viitab uuele, nimerohkele ajajärgule nimevalikus. Martna populaarseimate nimede kasutus osutab endiselt eelisnimede suurele osakaalule.

Palamuse uued nimed on tarvitusse hakanud järk-järgult ilmuma kõigest mõni kümnend varem, Alide 1850. aastatest alates, Linda ja esinimi Alma on esmakasutust leidnud alles 1880. aastatel. Martna uuemad edetabeli nimed on 1850-ndatel teekonda alustanud Kata ning 1860-ndate Juuli (juhukasutust ka varem), teised nimed on rohkem või vähem kasutust leidnud kogu perioodi vältel.

See rõhutab veel kord Martna ja Palamuse eesnimekasutuse muutuste suurt erinevust ning ajalist vahet.

\section{Mitmiknimed}

Kahe ja enama nime kasutus pakub huvi kui XIX sajandil levima hakanud ja omaks võetud nähtus. Selle levik viitab valmisolekule uuendusi vastu võtta ning näitab, mil moel uus mall oma kasutusse sobitub.

Esmalt antakse ülevaade poiste ning seejärel tüdrukute mitmiknimedest. Poistele ja tüdrukutele hakatakse kaksiknimesid panema üsna ühel ajal, ent üpris kiiresti kujuneb erinev kasutustava, kus tüdrukute nimistu kajastab uuendusi selgemini. Enamik mitmiknimesid on kaksiknimed. 


\subsection{Poiste mitmiknimed}

Martnas jääb kaksiknimede osa poiste puhul üsna tagasihoidlikuks (mitmiknimede kasutust vt joonis 8). Siiski esineb paar korduvat nime: August Johannes (3 korda), Johann Friedrich, Willem Heinrich (2). Üksikud kolmiknimed ilmuvad 1870. aastatel: Konrad Gustav Alexander, Erich Hans Arwid, Richard Conrad Ferdinand.

Kaksiknimed esinevad Martnas juba 1830. aastatel ning on poistel võõrapärasemad kui tüdrukutel. Olgu nimetatud nt Johann Friedrich, Willem Heinrich, Karel Aleksander, Wilhelm Alexander, Carl August. Siiski esineb neiski nn talupojanimesid (vrd tüdrukute nimedega), nt Kaarel.

Tavapärasemalt esinevad teise komponendina ka üksikult eelistatud nimed, nt Friedrich (7 korda), Johannes (6), August (5), Alexander, Johann (4). Erandiks on Friedrich, mis üksiknimena esineb vaid korra. Põhjuseks võib olla Priidu ja Priidiku populaarsus, mis Priidul ilmnes pigem vaatlusaluse ajavahemiku esimesel poolel, Priidikul aga teise poole lõpus. 1782. a hingerevisjoni järgi otsustades on nimed Priidu ja Priidik XIX sajandi Martnas pigem uudisnimed, esineb küll kuju Writs (EAA.1864.2.IV-9; 1782). Friedrich võib olla nimeandjate arvates võõrapärasesse nimemalli paremini sobitunud. Priidul, Priidikul ja Friedrichil on võinud olla mitmeid eeskujusid, sest XVIII sajandi lõpus - XIX sajandi algupoolel leiab Martnast sotsiaalselt kõrgemal positsioonil mitu Friedrichi-nimelist isikut. Martna köstri (1796-1835) David Gabriel Eylandti 12 last on võinud mitme nime vahendajaks olla, sh kannab tema esimene laps (1798-1866) kaksiknime Carl Friedrich ja viimane (1817-1897) Friedrich Gottlieb (Talvoja jt 2008: 76-77). Friedrichi nimi esineb ka sealsete mõisnike, von Ungern-Sternbergide suguvõsas, nt 1850. aastatel esineb nii vanemana kui ka ristivanemana Friedrich Adolph von Ungern-Sternberg.

Palamusel on korduvad kaksiknimed August Johannes (10 korda), August Julius (5), August Alexander, August Eduard, Carl Alexander, Hugo Oswald (4) jne.

Esimene kolmiknimi pandi Palamusel 1845. aastal (kokku leidus neid 6): Alexander Gustav Eduard. Vanemate positsioon ei selgu, ent vaderid on kõrgemast seisusest.

Palamuse poiste nimed on tüdrukute nimedega võrreldes võõrapärased. Nn talupojanimede näideteks saaksid olla Karel Eduard 1830. aastatest, Jürri Woldemar 1860-ndatest, Karel Julius 1870-ndatest, Eduard Mart, 
Hindrik Woldemar, Juhan Eduard, Julius Hindrik 1880-ndatest, Jüri Ferdinand 1890-ndatest.

Teise nimena esinevad kaksiknimedes sagedamini Eduard (26 korda), Alexander $\sim$ Aleksander (25), Johannes (24), Julius (13), Friedrich (10), August, Woldemar (8), Heinrich (7), Oswald, Rudolf(5). Kui silmas pidada, et kaksiknimede osa sajandi lõpupoole kasvab, siis selles loendis üllatavat ei leidu, tegemist on tavapäraste nimedega.

\subsection{Tüdrukute mitmiknimed}

Kaksiknimesid leidub Martna tüdrukutel juba vaadeldud perioodi alguses need on ilmselt selle piirkonna esimesi kaksiknimesid. Osa neist on kokku pandud tavapärastest tuttavatest laennimedest ning matkivad võõrapärast malli. Algusjärgus leiame sellised nimed kui Lisa Kadrina, Lowisa Anna, Anna Kadrina, Mina Katrina, Jula Lena, Teresa Lowisa. Uuritud aastatel esines korduvalt Anna Maria (6 korda), Katta Lowisa, Julie Pauline (3), Lisa Kadrina, Katta Maria, Lisa Maria, Elise Marie, Liisa Pauline (2). Kolmiknimesid leidub alates 1870. aastatest (kokku 5 nime).

Sagedamini esinevad teise nimena Maria/e (19 korda), Pauline (8), Lowisa/e (7); veel korduvad Helene, Johanna, Kadrina, Katrinale, Albertine, Carolina/e, Rosalie, millest enamik on ka üksiknimena populaarsed.

Palamusel leidub terve rida korduvaid kaksiknimesid, kõige sagedamini esineb nagu Martnaski kombinatsioon Anna Maria/e (42 korda, sh 28 korral Maria; samas Mariede hulk kasvab sajandi lõpupoole), Julie Marie/a (16), Amalie/a Marie/a (11, e-lõpulised variandid ülekaalus), Emilie Marie/a, Maria/e Elisabeth (9), Ida Rosalie, Lisa Maria/e (8), Alide Rosalie, Anna Elisabeth, Anna Rosalie (7) jne.

Esimese kolmiknime leiab Palamuse eesti pihtkonna tüdrukutelt juba vaatlusaluse perioodi esimesel kümnendil, 1830. aastatel, see on Anna Catharina Elisabeth (1839). Tüdruku isa on kubjas Mardi Jaak Sep (ema Liso) ehk siis lihtrahva lapsega tegemist polnud. Hilisematel kümnenditel esinevad nt Agathe Sophie Petronelda, Alide Mathilde Johanna, Anna Maria Elisabeth, Annette Elli Rosalie, Anni Hella Melanie, Elisabeth Marie Julie, Ida Anna Helene, Kattarine Marie Friederike, Mili Anne Marie.

Ka Palamuse tüdrukutel on kaksiknimesid, mille koosseisus on vähemalt üks traditsiooniline laennimi või hiljem ka uuema nime mugand. 
Taolisi kaksiknimesid esineb 1840. aastatel (Lisa Maria/e, Lena Lowisa, Anna Mina, Amalie Lisa, Lena Sohwia), kuid rohkem siiski aastatel 1870-1900. Kahe traditsioonilise nime koosesinemise näitena saab tuua nimed An Lena, An Lisa, Katta Lina. Korduvalt esinevad Lena Maria/e, Mali Marie/a, Mili Marie/a, Mina Rosalie, Lena Pauline, Lena Rosalie, Lisa Rosalie, Mili Rosalie. Haruldaste kaksiknimede näidetena võiks tuua Adi Pauline ja Rosi Pauline - Aadi ei esine üksikult üldse, ka Roosi on üsna harv nimi.

Suurem osa Palamuse kaksiknimedest koosneb siiski oma aja tavapärastest nimedest. Seda näitavad ka teise nimena esinevad nimed. Esile tõuseb üks nimi, see on Marie/a, mis esineb teise nimena 125 korral ja moodustab üle veerandi kõigist kaksiknime juhtudest. Järgmised sagedamini esinenud nimed kuuluvad sajandi viimaste kümnendite tavanimede hulka: Rosalie (76), Elisabeth (40), Lowisa (24), Pauline (19), Sophie/a (15), Wilhelmine/a (15), Mathilde (13), Alwine, Helene/a, Johanna (11), Emilie (10), Amalie, Rosine/a (7) jne.

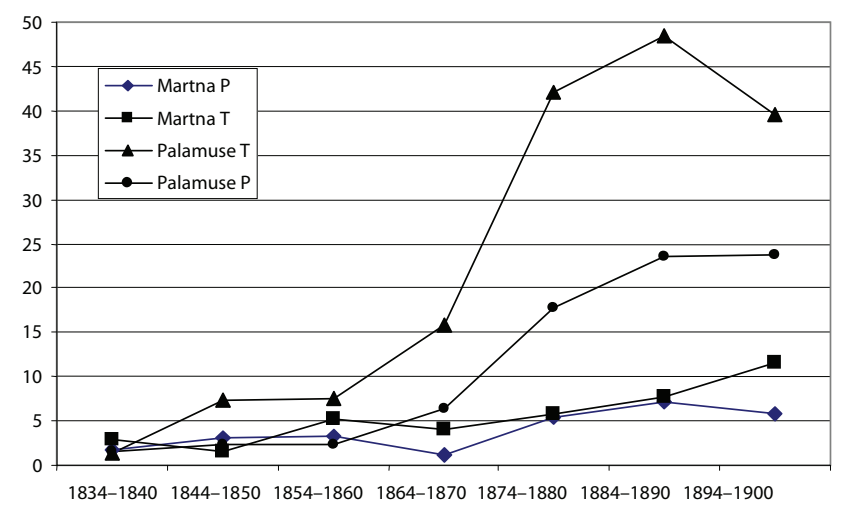

Joonis 8. Kahe ja enama nime kasutus Martnas ja Palamusel ( $\mathrm{P}$ - poisid, $\mathrm{T}$ - tüdrukud)

Eri piirkondade ning sugude võrdlus näitab, et mitmiknimede kasutus kasvab selle aja jooksul kõikjal, rohkem Palamusel ja eriti tüdrukutel. See näitab, et see uuendus on Palamusel kergemini vastu võetud - nagu 1900. a andmete põhjal kogu Tartumaal erinevalt Läänemaast, kus mõnes koguduses kaksiknimesid ei esine. Mitmiknimede panek on levinud tüüpilise moenähtusena eriti tüdrukute puhul, mis kinnitab arusaama 
naisenimede moe kiiremast vastuvõtust ja mehenimede suuremast traditsioonilisusest. Palamusel leidub isegi mitu näidet, kus tüdrukutele ja poistele nime panekul käituti isemoodi. Näiteks pandi kaksikutele erinev arv nimesid: poisile üks ja tüdrukule kaks nime, nt 1885 Julie Elisabeth ja Tawet, Amalie Rosalie ja August, 1887 Mili Marie ja Jaan, 1895 Alwine Rosalie ja August, Ida Helene ja August.

\section{XIX sajandi eesnimekasutuse iseloomulikke jooni}

Kahe siinkohal vaadeldud koguduse põhjal võiks XIX sajandi eesnimekasutuse kohta esile tuua järgmist.

Kõige rohkem teiseneb Tartumaa Palamuse tüdrukute eesnimekasutus. Esimesi muutusi võib Palamuse naisenimedes täheldada sajandi keskpaiku. Esmalt rikastub eelisnimestik Liisu ja Leenu kõrval nimekujudega Liisa ja Leena. Varakult ilmub Annile lisaks Anna (seda ka Martnas), seejärel Marile Marie/a ja Juulale Julie. 1870. aastatel on peale laennimede uuemate asenduste laia tarvitusse jõudnud juba hulk päris uusi nimesid. Sajandivahetuseks on Palamuse naisenimed vahetunud. Märke on juba uue moe, eestipäraste nimede omaksvõtust. Seega on eri laadi muutused toimunud väga kiiresti, mõnekümne aasta jooksul - eriti kui senist pikaajalist üsna ühtlast kasutust silmas pidada.

Martna tüdrukute puhul viitab esimestele muutustele Anna tõus eelisnimede pingereas ning Maria/e ilmumine sellesse. See juhtub 1870.-1880. aastatel ning sellega jõuab Martna sajandi lõpuks esimesse etappi (käibel olnud nimede rahvusvahelised variandid), uued lisandunud võõrapärased nimed on osutus järgmisele etapile.

Muutused mehenimede valikus on hilisemad, 1870.-1880. aastatest. Palamusel, kus naisenimede valik kiiremini muutus, hakkavad mehenimed varem uute vastu vahetuma. Sajandi lõpuks jõutakse olukorda, kus eelisnimede seas domineerivad laennimede võõrapärased variandid või päris uued nimed.

Martna poiste 1890-ndate eelisnimede hulgas on rida laennimesid, mis leidusid seal ka 70 aastat varem, lisaks on paar laennime uuemat varianti ning päris uut nime.

Sama olukorda kinnitab mitmiknimede omaksvõtt. Palamusel on sellised nimed kiiremini ja oluliselt sagedamini pruuki tulnud. Nii ühes kui ka teises koguduses saavad tüdrukud kaksiknimesid rohkem. Palamuse 
tüdrukutel sobitatakse esmalt olemasolevasse malli meelsasti sel ajal tavapäraseid laennimesid. Kaksiknimede levides kombineeritakse eeskätt vastava aja tavanimesid.

1830. aastate nimekasutus kajastab ilmselt üsna hästi varasemat, XVIII sajandi olukorda. Erineda võivad iga piirkonna konkreetsed nimed ja need vahetuvad tasapisi - nagu need varemgi vahetusid, sellest hoolimata, kui üheülbaline pilt tänapäeva jaoks tunduda võib -, ent valdavalt ollakse endisaegse seisukorra, aja jooksul muganenud laennimede juures. XVIII sajandiga võrreldes tundub kasutusel olevate nimede arv isegi vähenenud olevat ning neil on nimeandmisel vastavalt suurem osakaal. Eelisnimede osakaal hakkab XIX sajandi teisel poolel vähenema, kiiremate ja ulatuslikumate muutuste puhul (nagu siin käsitletud Palamuse naisenimed) olulisel määral. Uute nimede kasutusele tulek kergendab üha uute nimede lisandumist, samas jäävad nende kõrvale mõneks ajaks ka varasemad nimed, mis suurendab kasutusel olevate nimede hulka veelgi.

Uute nimede vahendajatena tasub otsida kohapealseid autoriteetseid nimekandjaid, kes on võinud eeskujuks olla.

Siinne ülevaade kinnitab, et ka Eestis toimusid eesnimistus XIX sajandil olulised muutused: seni traditsioonilised laennimed vahetusid nende võõrapäraste variantide vastu, mis omakorda kergendas teiste uute nimede kasutusele tulekut. Ka leidis kinnitust, et muutused haarasid kiiremini ja ulatuslikumalt naisenimesid. Naisenimede arv ületas mehenimede arvu ning koos kasutatavate nimede suurema arvuga vähenes ka nende osakaal.

\section{Kirjandus}

Annus, Endel 2000. Eesti kalendrikirjandus 1720-1900. Tallinn: Eesti Akadeemiline Raamatukogu.

Henno, Kairit 2000. Poeglaste eesnimed Pöide eesti koguduse 1801.-1840. aasta sünniregistreis. - Emakeele Seltsi aastaraamat 44-45 (1998-1999). Tartu, 30-41.

Hussar, Annika 2009. Changes in naming patterns in 19th century Estonia. Discarding the names of parents and godparents. - Names in Multilingual, Multi-Cultural and Multi-Ethnic Contact: Proceedings of the 23rd International Congress of Onomastic Sciences. August 17-22. York University, Toronto, Canada. Ed. Wolfgang Ahrens, Sheila Embleton, André Lapierre. Toronto, Canada: York University, 519-525. 
Kaugerand, Jüri 2006. Kuusalu kihelkonna laste nimed aastatel 1834-1850. Bakalaureusetöö. Käsikiri Tallinna Ülikooli eesti keele ja kultuuri instituudis.

Kiviniemi, Eero 1982. Rakkaan lapsen monet nimet. Suomalaisten etunimet ja nimenvalinta. Espoo.

Must, Aadu 2000. Eestlaste perekonnaloo allikad. Tartu: Kleio.

Pärsik, Liisi, Taavi Pae 2011. Eesnimede piirkondlikud erinevused Eestis 1840. aastal. - Akadeemia 3, 511-535.

Rajandi, Edgar 1963. Nimevähesusest XVIII sajandi esimesel poolel. - Keel ja Kirjandus 3, 177-178.

Rajandi, Edgar, Helmut Tarand 1970. Eesti eesnimedest Mats Tõnissoni tähtraamatutes. - Emakeele Seltsi aastaraamat 16 (1970). Tallinn: Eesti Raamat, 125-141.

Rajandi, Edgar, Helmut Tarand 1971. Möödunud aastakümne eelisnimed. Keel ja Kirjandus 4, 207-216.

Roos, Eduard 1962. Eesti eesnimede ajaloost XIX ja XX sajandi vahetusel. Keel ja Kirjandus 7, 412-421.

Rootsmäe, Lemming 1969. Võnnu kihelkonna isikunimed XVIII sajandil. - Keel ja Kirjandus 10, 623-624.

Saari, Henn 1990. Ein statistisches Modell der Vornamenwahl. (= Preprint KKI-67.) Tallinn.

Talvoja jt 2008 = Rait Talvoja, Salme Niilisk, Vilma Strauss. Kuluse - Martna kirikumõisa küla. Kodulooline uurimus. Juuru.

\section{Materjal}

Kuusalu kirikuraamatud

EAA.1216.1.22; 1834-1843

EAA.1216.1.23; 1844-1853

Martna kirikuraamatud

EAA.1246.1.21; 1834-1843

EAA.1246.1.22; 1844-1853

EAA.1246.1.23; 1854-1863

EAA.1246.1.24; 1864-1873

EAA.1246.1.211; 1874-1883

EAA.1246.1.231; 1892-1919

EAA.1864.2.IV-9; 1782 (1782. a, 4. hingerevisjon) 
Palamuse kirikuraamatud

EAA.1261.1.59; 1834

EAA.1261.1.60; 1835

EAA.1261.1.61; 1836

EAA.1261.1.62; 1837

EAA.1261.1.63; 1838

EAA.1261.1.64; 1839

EAA.1261.1.65; 1840

EAA.1261.1.66; 1841

EAA.1261.1.67; 1842

EAA.1261.1.68; 1843

EAA.1261.1.69; 1844

EAA.1261.1.70; 1845

EAA.1261.1.71; 1846

EAA.1261.1.72; 1847

EAA.1261.1.73; 1848

EAA.1261.1.74; 1849

EAA.1261.1.75; 1850

EAA.1261.1.76; 1851

EAA.1261.1.77; 1852

EAA.1261.1.79; 1854

EAA.1261.1.80; 1855

EAA.1261.1.81; 1856

EAA.1261.1.82; 1857

EAA.1261.1.83; 1858

EAA.1261.1.84; 1859

EAA.1261.1.644; 1860-1873

EAA.1261.1.650; 1874-1903

Annika Hussar

eesti keele ja kultuuri instituut

Tallinna Ülikool

Narva mnt 25

10120 Tallinn

Annika.Hussar@tlu.ee 


\title{
Changes in the use of first names in the $19^{\text {th }}$ century with a focus on Martna and Palamuse
}

\author{
Annika Hussar
}

The article provides an overview of changes in the use of first names in $19^{\text {th }}$ century Estonia.

Similarly to other countries, in the second half of the $19^{\text {th }}$ century Estonia witnessed major changes in the use of first names: new and previously unknown names were adopted, the name stock started to increase, especially the range of female names increased, double names were introduced, and godparents' names were dropped from children's names.

The replacement of first names took place by stages: 1) traditional loan names (e.g. Mari, Jaan), 2) international variants of the same names (e.g. Marie, Johannes), 3) new international names (e.g. Alma, Rudolf), 4) Estonian names (e.g. Salme, Ülo).

Different regions revealed considerable differences; both the used first names and the rate of adopted innovations were different.

The article compares the adoption of new names at Martna, a conservative congregation in western Estonia, and Palamuse, a congregation more open to innovations in northern Tartumaa, in 1834-1900.

At Martna new names were widespread as late as at the end of the century; at Palamuse they were common already in the 1870s. In the 1890s some Palamuse

girls were already given modern Estonian names (e.g. Linda, Salme among the most popular names). The fashion of male names was slower to change, and Estonian-style names became fashionable as late as in the $20^{\text {th }}$ century. At Palamuse double first names were adopted more quickly and more extensively (at the end of the century about 40 per cent of girls and almost 24 per cent of boys received two names); at Martna the use of double first names remained modest.

Apart from more general attitudes, such as readiness for innovations activeness of the national movement in the region, spread of education, and links with major centres - changes in the use of first names reflect the role of specific examples in the spread of new names.

Keywords: onomastics, anthroponyms, first names, double first names 